\title{
Landscape Aesthetics Theories in Modeling the Image of the Rurban Landscape
}

\author{
Erika Zaleskienë*, Indrẻ Gražulevičiūtė-Vileniškè \\ ${ }^{1}$ Kaunas University of Technology, Faculty of Civil Engineering and Architecture, Studentu st. 48, LT-51367 Kaunas, \\ Lithuania.
}

*Corresponding author: erika.brinkyte@gmail.com

cross ref http://dx.doi.org/10.5755/j01.sace.7.2.6731

In the era of massive urbanization and suburbanization the urban fringe is no longer the clear line separating urban and rural or natural landscapes, but often the continuous fragmented mix of rural and urban features. These territories of ruralurban interface - rurban landscapes - become the everyday living and working environment of the increasing numbers of people around the world including Lithuania. Those, who have a possibility to choose to live in rurban areas usually expect the combination of benefits of life in the city and in the countryside. However, what they more often get is ether visual chaos or suburban uniformity. This encourages looking at the aesthetics of rurban landscapes more carefully. Thus in this research we raise and try to answer the following questions: what makes particular landscapes acceptable and attractive to us and how this can be applied to rurban landscapes?; how rurban landscape aesthetics could be regulated or modeled? In the first part of our research we have discussed the excising landscape aesthetics theories and analyzed whether and how they can be applicable to rurban landscapes. In the second part of the research we have tried to answer the question of rurban landscape assessment and modeling integrating the approaches by W. Nohl, A. Ode et al. and M. Tveit et al. and Lithuanian experience of landscape aesthetic assessment and rurban landscape peculiarities. The research allowed formulating the conclusions regarding the importance of aesthetics in our everyday living landscapes including the dynamic and complex rurban landscapes. It has demonstrated that the entire spectrum of landscape aesthetics theories can be successfully applied to these particular landscapes and suggest important criteria for their aesthetic assessment. These findings suggested our approach towards developing the image of rurban landscapes presented in this research integrating the aesthetic perceptual categories under sustainable landscape conditions by W. Nohl and the system of visual landscape characterization concepts by Ode et al. and M. Tveit et al.

Keywords: aesthetics, landscape aesthetics theory, landscape assessment, landscape modelling, rurban landscape.

\section{Introduction}

Aesthetics may be defined narrowly as the theory of beauty (Slater, 2014). Aesthetics is broader in scope than the philosophy of art, which comprises one of its branches. It deals not only with the arts but also with those responses to natural objects, including landscapes, that find expression in the language of the beautiful and the ugly. Contemporary discipline of aesthetics incorporates three approaches: the study of the aesthetic concepts, the study of certain states of mind - responses, attitudes, emotions that are held to be involved in aesthetic experience, and the study of the aesthetic object (Munro, 2013). Considering these subjective and objective, abstract and concrete aspects of aesthetics, landscape aesthetics can be defined as the landscape quality perceived using all human senses (including sight); as far as the subject perceives 85 percent of environment - object - using sight and gets specific spiritual-aesthetic, emotional-aesthetic experience, it can be stated that visual quality constitutes the basis of aesthetic quality of landscape. Moreover, the aesthetic experience of landscape is determined both by the personal qualities of the perceiver and by his or her cultural background - cultural context (Kamičaitytè-Virbašienè, 2003).

J. Kamičaitytė-Virbašienè (2003) and A. Ode et al. (2008) had published the extensive literature reviews on landscape aesthetic assessment approaches. Even if the philosophical interest in the discipline has intensified already in the $18^{\text {th }}$ century with the advent of the concept of the sublime (Slater, 2014), which is applicable to landscape, the reviews reveal that the greatest interest in landscape aesthetics as scientific discipline and its scientific measurement was demonstrated in the second half of the $20^{\text {th }}$ century both in the world and in Lithuania; meanwhile, the 
contemporary research ether tries to integrate the aesthetics as one of the dimensions of landscape sustainability, to reconcile ecology and aesthetics, either more concentrates on ecological, economic or social questions, on application of new technologies in landscape research leaving landscape aesthetics as a secondary matter. The experience in this field ranges from widely known studies by J. Appleton (1975), R. Kaplan and S. Kaplan (1989), J. I. Nassauer (1988) and others expressing different attitudes towards landscape preferences to more recent approaches trying to reconcile ecology and aesthetics, aesthetics and environmental sustainability including J. I. Nassauer (1988; 2007), C. Steinitz (1990), W. Nohl (2001), R. L. Musacchio (2009) and many others. It is paradoxical that in Lithuania the major work in the field of landscape aesthetic assessment was carried out during the Soviet period. V. Stauskas (1966), P. Kavaliauskas (1975), G. J. Daniulaitis (1980), M. Purvinas (1983), J. Bučas (1980; 1983), K. Ėringis and A. R. Budriūnas (2000), G. J. Daniulaitis and J. KamičaitytèVirbašienè (2002), J. Kamičaitytė-Virbašienè (2001; 2003) had addressed the questions of landscape visual quality and, more generally, aesthetics, and presented different theoretical approaches and methodologies for landscape valuation.

The protection of landscape's beauty has long-lasting traditions in the United States and in Britain and other European countries. The use and protection of landscape's beauty is strongly related with protected areas, which, depending on landscapes of different counties, cover from 0.15 percent to 15 percent of the territory. Landscape aesthetics, however, is intangible resource of our living environment (Kamičaitytè-Virbašienè, 2003), thus not only the natural and cultural landscapes of exceptional aesthetic quality, but also our everyday living and working environment should be the object of landscape aesthetic research. This research focuses on landscapes of different types and qualities emerging in the areas or rural-urban interface - the rurban landscapes. We argue that these landscapes, with ongoing urbanization becoming everyday reality of increasing numbers of population around the world, not only reflect the general challenges of landscape aesthetics, but also present specific and yet unsolved problems (table 1).

The aim of the research was to demonstrate the applicability of different landscape aesthetics theories to rurban landscapes and to present new possibilities of modeling their distinctive aesthetic image. In order to reach the aim of the research, we have carried out the review of foreign and Lithuanian literature and preliminary observations on site in the zones of influence of large Lithuanian cities. We have employed the analysis, synthesis, comparison and generalization of gathered material.

\section{Review of landscape aesthetics theories and their applicability to rurban landscapes}

Within the field of landscape aesthetics several groups theories for explaining landscape perception and preferences can be distinguished - so-called evolutionary or biological theories (landscape preferences reflect landscape qualities satisfying human biological needs to survive and thrive as a species), cultural preference theories (perception and experience of a landscape are predominantly dependent on the cultural background and personal attributes of the observer) and mixed theories (Tveit et al., 2006) (Table 2). Based on M. Tveit et al., (2006) and A. Ode et al., (2008) and other sources (Nassauer, 1995; Kamičaitytė-Virbašiene 2003; Stedman and Ingalls 2014) below we provide the short review and description of these theories.

- The prospect-refuge theory - evolutionary or biological landscape preference theory - developed by J. Appleton in 1975 underlines the humans as both predator and prey, which would prefer landscapes offering both prospect and refuge - the possibility of "seeing without being seen". According to this theory, this ability is an indicator of environmental conditions favorable to our biological survival and landscape providing such features is simultaneously

Table 1. Some challenges related to landscape aesthetics

\begin{tabular}{|c|c|}
\hline General & Specific to rurban landscapes \\
\hline $\begin{array}{l}\text { - Landscape aesthetics as component of quality of life } \\
\text { - } \text { Asychological, emotional, spiritual meaning) } \\
\text { - Importance of landscape aesthetics as economic category } \\
\text { - Insufficient interest in landscape aesthetics in recent } \\
\text { decades } \\
\text { - Turn from qualitative to quantitative in landscape } \\
\text { research } \\
\text { - Predominant rationalistic, economic, productive interests } \\
\text { in landscape formation } \\
\text { - Predominance of ecological thought in landscape } \\
\text { research } \\
\text { - Problems of reconciling ecology and aesthetics, } \\
\text { aesthetics and ethics in landscape research } \\
\text { - Challenges of integrating subjective assessments } \\
\text { and objective landscape characteristics in landscape } \\
\text { aesthetics }\end{array}$ & $\begin{array}{l}\text { - Rapid changes and instability of rurban landscape, lack of stable } \\
\text { - } \text { aesthetic categories } \\
\text { - Lack of stable and positive image and distinctive aesthetics of rurban } \\
\text { - Lack of historical identity of rurban areas } \\
\text { - Difficulties of "reading" complex rurban landscapes } \\
\text { - Problems of visual chaos and uniformity of rurban landscapes } \\
\text { - Aesthetic fragmentation in rurban landscapes } \\
\text { - Rurban landscapes are not viewed as aesthetic resource } \\
\text { - Challenge of new rurban aesthetics } \\
\text { - Strong contradictions and conflicts between the aesthetics and ecology } \\
\text { in rurban landscapes } \\
\text { - Contradictions and conflicts between rural and urban aesthetics in } \\
\text { - Contban landscapes } \\
\text { - Laburban aesthetics in rurban landscapes } \\
\text { systematic formation }\end{array}$ \\
\hline
\end{tabular}


a source of aesthetic pleasure. Human habitat theory by G. H. Orians similarly links aesthetic pleasure with the fulfillment of human biological needs (Tveit et al., 2006).

- Information processing theory, another evolutionary theory by R. Kaplan and S. Kaplan (1989) is based on the human need for information and the ability to process it in order to survive. Consequently easily legible landscapes would be favored by natural selection, and the genetic bases to appreciate such landscapes would still be inherent in people today (Tveit et al., 2006; Ode et al., 2008).

- Biophilia or Biophilia hypothesis by S. R. Kellert and E. O. Wilson bases aesthetic appreciation of landscape on the human biological need to affiliate with nature. This evolutionary landscape preference theory emphasizes the importance of natural diversity of species and of landscape types and the tendency naturally inherent in people through evolutionary history to focus on and appreciate life and lifelike processes (Tveit et al., 2006; Ode et al., 2008; Stedman and Ingalls, 2014).

- The theory of restorative landscapes links cultural and biological bases for landscape appreciation and emphasizes the links between the ability of environments to enhance recovery of mental energies and landscape preferences. It underlines the relationships between the naturalness of a scene and human restoration or stress recovery; meanwhile, the naturalness has also been found to enhance landscape preference (Ode et al., 2008).

- Another mixed biological-cultural ecological aesthetics theory by A. Carlson and P. H. Gobster links preferences for landscape with ethics, suggesting a preference for ecologically sound landscapes (Tveit et al., 2006). A. Jorgensen (2011) has also expressed similar view.

Table 2. Theories of landscape preference summarized from M. Tveit et al. (2006) and A. Ode et al. (2008) and their applicability and relevance to rurban landscape determined in this research

\begin{tabular}{|c|c|c|c|c|c|}
\hline \multicolumn{4}{|c|}{ Theory } & \multicolumn{2}{|l|}{ Relevance to rurban landscapes } \\
\hline Category & Title & Authors, sources & Year & Aspects of relevance & $\begin{array}{l}\text { Degree of } \\
\text { relevance }\end{array}$ \\
\hline \multirow{3}{*}{ 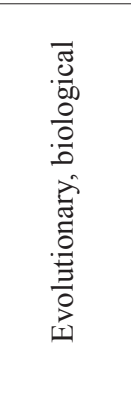 } & $\begin{array}{l}\text { Prospect-refuge } \\
\text { theory }\end{array}$ & J. Appleton & 1975 & $\begin{array}{l}\text { Spatial structure of various types of rurban } \\
\text { landscapes (both with predominant natural } \\
\text { and rural and urban features) can provide the } \\
\text { possibility of "seeing without being seen" }\end{array}$ & High \\
\hline & $\begin{array}{l}\text { Information } \\
\text { processing theory }\end{array}$ & $\begin{array}{l}\text { R. Kaplan and } \\
\text { S. Kaplan }\end{array}$ & $1982-1989$ & $\begin{array}{l}\text { Some features of rurban landscapes, for example } \\
\text { the relicts of historic rural landscapes, could be } \\
\text { easily readable }\end{array}$ & Medium \\
\hline & $\begin{array}{l}\text { Biophilia, } \\
\text { Biophilia } \\
\text { hypothesis }\end{array}$ & $\begin{array}{l}\text { S. R. Kellert and } \\
\text { E. O. Wilson }\end{array}$ & 1993 & $\begin{array}{l}\text { Diversity of landscape types and their fragments } \\
\text { in rurban areas, presence of fragments of natural } \\
\text { environment and processes of abandonment and } \\
\text { renaturalization in rurban landscapes }\end{array}$ & High \\
\hline \multirow{3}{*}{$\stackrel{\overrightarrow{0}}{\stackrel{\ddot{x}}{\Sigma}}$} & $\begin{array}{l}\text { Restorative } \\
\text { landscapes }\end{array}$ & $\begin{array}{l}\text { R. Kaplan and } \\
\text { S. Kaplan, R. S. Ulrich, } \\
\text { T. Hartig et al., } \\
\text { T. R. Herzog et al., } \\
\text { E. Real et al., C. } \\
\text { Hagerhall et al. }\end{array}$ & 1989-2004 & $\begin{array}{l}\text { Presence of fragments of natural environment in } \\
\text { rurban landscapes and possibilities to use them } \\
\text { for recreation }\end{array}$ & High \\
\hline & $\begin{array}{l}\text { Ecological } \\
\text { aesthetics }\end{array}$ & $\begin{array}{l}\text { P. H. Gobster, } \\
\text { A. Carlson }\end{array}$ & $1999-2001$ & $\begin{array}{l}\text { Presence of fragments of natural environment in } \\
\text { rurban landscapes, importance of ecology in the } \\
\text { zones under pressure of urbanization }\end{array}$ & Medium \\
\hline & Topophilia & Y. Tuan & 1974 & $\begin{array}{l}\text { The relicts of rural environment in rurban } \\
\text { landscapes may be the objects of topophilia, } \\
\text { topophilia is also important in developing } \\
\text { communities in the rurban areas }\end{array}$ & High \\
\hline \multirow{4}{*}{$\underset{\Xi}{\stackrel{\overparen{Z}}{\Xi}}$} & Formal aesthetics & S. Bell & 1999 & $\begin{array}{l}\text { Formal landscape aesthetics cab be useful tool } \\
\text { for describing cultural picturesque landscapes } \\
\text { in the rurban areas; however, the complexity } \\
\text { or rurban landscapes limits the application } \\
\text { possibilities of this theory }\end{array}$ & Low \\
\hline & $\begin{array}{l}\text { Landscape } \\
\text { heritage / historic } \\
\text { landscapes }\end{array}$ & $\begin{array}{l}\text { D. Lowenthal, } \\
\text { G. Fairclough et al. }\end{array}$ & $1979-1999$ & $\begin{array}{l}\text { Presence of relicts of historic rural landscapes in } \\
\text { rurban areas }\end{array}$ & High \\
\hline & $\begin{array}{l}\text { Spirit of place } \\
\text { / genius loci / } \\
\text { vividness }\end{array}$ & $\begin{array}{l}\text { K. Lynch, R. B. Litton, } \\
\text { R. B. Litton et al., } \\
\text { S. Bell }\end{array}$ & $1960-1999$ & $\begin{array}{l}\text { Presence of distinctive relicts of historic rural } \\
\text { and natural landscapes in rurban areas, the need } \\
\text { to develop the distinctive image of rurban areas }\end{array}$ & High \\
\hline & Aesthetics of care & $\begin{array}{l}\text { J. I. Nassauer, } \\
\text { S. R. J. Sheppard }\end{array}$ & $1995-2001$ & $\begin{array}{l}\text { Aesthetics of care is important preserving the } \\
\text { relicts of historic rural landscapes and developing } \\
\text { high quality living environment with local } \\
\text { centers and public spaces in rurban areas }\end{array}$ & Medium \\
\hline
\end{tabular}


This theory sees landscape preferences from an ethical perspective: if a landscape is known to be ecologically healthy then it will be preferred. According to J. KamičaitytèVirbašiene (2003), similar approach dominates in landscape valuation in Lithuania: the intensity of human impact is seen as inversely proportional to landscape's aesthetic quality, and the most natural landscapes are seen as the most scenic. However, such approach is applicable only to specific categories of landscape.

- The theory by Y. Tuan called topophilia - the love of place - focuses on the cultural dimension of preference and is defined as the affective bond with one's environment person's mental, emotional, and cognitive ties to a place (Heimer 2005). The topophilia hypothesis emphasizes the personal attributes - age, gender, occupation, hobbies, academic background, familiarity etc. - as important factors for landscape preference (Tveit et al., 2006).

- Formal aesthetics theory, another cultural theory of landscape preference, is based on design theories and attempts at describing landscape using the concepts and terms of aesthetic philosophy and art criticism in order to provide a language to describe the aesthetic qualities of landscape, mainly linked to design, planning, and assessment. Here an expert with formal education in aesthetics and art criticism qualified to evaluate the visual quality of landscape plays an important role (Tveit et al., 2006).

- Landscape heritage or historic landscapes approach to landscape preferences presented by D. Lowenthal and G. Fairclough maintains that historical dimension and historical elements are important for landscape perception and preference. Landscapes that contain both past and present can provide their residents with a feeling of community integrity and quality. Historical continuity in landscape, landscape elements that, through their different form, material, wear and patina, differ from recently built structures provide a depth of meaning, a sense of time, recreational resources and contribute to landscape aesthetics (Tveit et al., 2006; Ode et al., 2008). J. Kamičaitytè-Virbašienè (2003) identifies similar cultural heritage protection concept in Lithuanian landscape valuation practice related to historical-cultural approach towards landscape visual quality. Here cultural landscapes are subdivided into organically developed, intentionally planed and associative, the visual quality of which is determined by different factors - a specific combination of physical components and visual expression determined by different land use, compositional factors or associative values.

- Spirit of place, genius loci, vividness or imageability approach presented by K. Lynch, R. B. Litton. S. Bell links landscape preferences with such special landscape features as identifiable uniqueness, distinction, sometimes known as genius loci or sense of place or "the quality in a physical object which gives it a high probability of evoking a strong image in any given observer" (Tveit et al., 2006).

- The aesthetics of care theory is linked with the works of J. I. Nassauer and S. R. J. Sheppard; here the signs of landscape maintenance - visual "cues of care" (mowing, tidy fences and footpaths, bright flowers, and trimmed, straight edges) - are used to explain landscape preference (Nassauer, 1995; Tveit et al., 2006; Ode et al., 2008).
The review of different landscape aesthetics theories carried out in the frame of this research demonstrates, that part of them are clearly oriented towards natural landscape and human survival, the other part - towards culturized environments transformed by man, and the third group tries to integrate or reconcile these opposite approaches. This transition from nature to culture (biological (nature oriented) - mixed - cultural) corresponds to transitory nature of rurban landscapes (rural or natural landscape with urban features - urban landscape with rural features); moreover, each rurban landscape is a mix of rural, natural, urban features. That's why we conclude that it is not possible to limit the aesthetic analysis of rurban landscapes only with biological or cultural landscape aesthetics theories and criteria deriving from them. Table 2 demonstrates the applicability and relevance of landscape aesthetics theories to rurban landscapes.

\section{Possibilities of assessment of aesthetic changes of rurban landscapes}

M. Antrop (2008) in his landscape research priorities for the future indicates that "landscape is a basic theme in strategic environmental and policy assessment. There is no such thing as a non-landscape, so all landscapes should be considered in all policy domains" and rurban landscapes are not an exception. He also underlines the need to encourage practical applications for policy making of scientific landscape research, the need of efficient monitoring of landscape changes, the need to focus more on prognosis and scenarios and to develop and test indicators of landscape change.

Another important theme in landscape and rurban landscape in particular research is the above-discussed landscape aesthetics and its changes. Even if the landscape researchers agree that landscapes aesthetics and scenery evaluation should be an essential part of any comprehensive understanding of landscape (Ewald, 2001) and optimistically suggest that contemporary landscape aesthetics becomes increasingly interdisciplinary with contributions from arts, philosophy, and social sciences (Jorgensen 2011); however, the analysis of landscape research trends shows that "aesthetic" is often replaced by "visual" and "place" is replaced by "picture". The example of such approach is the landscape aesthetics research using photographs and other visual media to represent real world environments that started in 1960' (Jorgensen, 2011). However, given the importance of informational content for aesthetic perception (Nohl, 2001), the need to expand the vision of landscape from a "picture" to a "place" (Jacobs, 2011) with its past and present is evident.

The above mentioned landscape research challenges are relevant in monitoring and assessing the aesthetic transformations of rurban landscapes and directing them towards more sustainable way - developing a and maintaining specific landscape character (distinct, recognisable and consistent pattern of elements in the landscape that makes one landscape different from another, rather than better or worse (Swanwick, 2002), regulating landscape's visual quality (Kamičaitytè-Virbašienè, 2003) 
or modeling and developing a specific aesthetic image of specific rurban area. The analysis of literature (of abovepresented landscape aesthetics theories and assessment approaches in our previous research (Zaleskienè et al., 2013)) has demonstrated that comprehensive landscape characterization methodology based on abstract concepts complexity, coherence, disturbance, stewardship, imageability, visual scale, naturalness, historicity, ephemera - and landscape dimensions, attributes, and indicators related to each one of them (Table 3) developed by M. Tveit et al. (2006) and A. Ode et al. (2008) answers to these basic challenges and needs of landscape aesthetic assessment and assessment of landscape changes and is suitable for rurban landscape assessment. Below we have distinguished several aspects justifying this suitability:

- it links landscape aesthetics theories with landscape assessment methodology, which can be successfully applied in practice (for example, the concept of complexity derives from theories of Information processing and Biophilia, which both underline landscape diversity);

- it allows using different sources of information (landscape photos, orthophotos, land cover data, and field observations) and avoiding to replace "place" by "picture" and "aesthetic" by "visual" (Table 3);

- it allows integrating general preferences and abstract judgments (for example, whether landscape is natural or coherent or not) with concrete quantitative and qualitative features of landscape aesthetic resources objective indicators (Kamičaitytè-Virbašienè, 2003): to integrate the subjective and objective in landscape valuation (table 3);

- it provides the possibility of involvement of experts and society in landscape assessment: landscape preferences expressed by the public and experts - general impression - can be integrated with expert assessment using this methodology. According to A. Ode et al., (2008), "landscape indicators provide possibilities for a more objective basis for identifying landscape character through dividing the totality of our visual perception of the physical landscape into quantifiable characteristics". Good example of such attempt is the research by D. Burgess et al. (2012), where they linked landscape preferences expressed by respondents with qualitative and quantitative features of landscapes under valuation using the concepts of

Table 3. Some indicators of coherence of landscape and possibility to determine them using different data sources from A. Ode et al. (2008)

\begin{tabular}{|c|c|c|c|c|}
\hline Concept & \multicolumn{4}{|c|}{ Data source } \\
\hline $\begin{array}{l}\text { Coherence - } \\
\text { enhances people's } \\
\text { ability to orient } \\
\text { themselves, both } \\
\text { in time and space, } \\
\text { which is dependent } \\
\text { on the readability of } \\
\text { the landscape }\end{array}$ & $\begin{array}{l}\text { Landscape photos } \\
\qquad \begin{array}{l}4 \\
4\end{array}\end{array}$ & 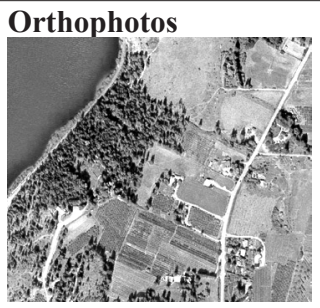 & Land cover data & Field observations \\
\hline \multicolumn{5}{|c|}{ 1. Spatial arrangement of water } \\
\hline Presence of water & $\begin{array}{l}\text { \% of water cover } \\
\text { Percent }\end{array}$ & $\begin{array}{l}\% \text { of water cover } \\
\text { Percent }\end{array}$ & $\begin{array}{l}\% \text { of water cover } \\
\text { Percent }\end{array}$ & $\begin{array}{l}\text { Proportion of water cover } \\
(1-4) \\
(1-\text { absent; } 2 \text {-moderate; } \\
3 \text {-average; } 4 \text { - high) }\end{array}$ \\
\hline $\begin{array}{l}\text { Correspondence of } \\
\text { land form and water } \\
\text { location }\end{array}$ & $\begin{array}{l}\% \text { of area in correspon- } \\
\text { dence } \\
\text { Percent }\end{array}$ & $\begin{array}{l}\% \text { of area in } \\
\text { correspondence } \\
\text { Percent }\end{array}$ & $\begin{array}{l}\% \text { of area in } \\
\text { correspondence } \\
\text { Percent }\end{array}$ & $\begin{array}{l}\text { Proportion of area in cor- } \\
\text { respondence } \\
\text { (1-4) } \\
\text { (1-absent; 2-moderate; } \\
\text { 3-average; 4-high) }\end{array}$ \\
\hline \multicolumn{5}{|c|}{ 2. Spatial arrangement of vegetation } \\
\hline $\begin{array}{l}\text { Correspondence with } \\
\text { natural conditions }\end{array}$ & $\begin{array}{l}\% \text { of area in } \\
\text { correspondence } \\
\text { Percent }\end{array}$ & $\begin{array}{l}\% \text { of area in } \\
\text { correspondence } \\
\text { Percent }\end{array}$ & $\begin{array}{l}\% \text { of area in } \\
\text { correspondence } \\
\text { Percent }\end{array}$ & $\begin{array}{l}\text { Proportion of area in cor- } \\
\text { respondence } \\
\text { (1-4) } \\
(1-\text { absent; } 2 \text { - moderate; } \\
3 \text {-average; } 4 \text { - high) }\end{array}$ \\
\hline Fragmentation & & $\begin{array}{l}\text { Fragmentation indices } \\
\text { (FRAGSTAT) } \\
\text { Absolute value }\end{array}$ & $\begin{array}{l}\text { Fragmentation indices } \\
\text { (FRAGSTAT) } \\
\text { Absolute value }\end{array}$ & \\
\hline $\begin{array}{l}\text { Repetition of pattern } \\
\text { across the landscape }\end{array}$ & $\begin{array}{l}\text { Presence of repeated pat- } \\
\text { terns } \\
(1-4) \\
(1-\text { absent } ; 2-\text { moderate; } \\
3 \text {-average; } 4 \text { - high })\end{array}$ & $\begin{array}{l}\text { Autocorrelation indices } \\
\text { (GIS) } \\
\text { Absolute value }\end{array}$ & $\begin{array}{l}\text { Autocorrelation indices } \\
\text { (GIS) } \\
\text { Absolute value }\end{array}$ & $\begin{array}{l}\text { Presence of repeated } \\
\text { patterns } \\
(1-4) \\
(1-\text { absent } ; 2 \text { - moderate; } \\
3 \text {-average; } 4 \text { - high) }\end{array}$ \\
\hline
\end{tabular}


complexity, coherence, legibility and mystery by S. Kaplan and R. Kaplan (1989).

- the methodology is suitable for assessment of landscape changes, landscape monitoring, making prognosis and modeling of landscape development (for example, assessing different landscape development scenarios) that are important for dynamic rurban landscapes;

- it integrates historical dimension (historicity), and non-tangible, associative aspects (historicity, imageability) especially relevant for rurban landscapes with the relicts of historic rural landscapes;

- the methodology is flexible and different sets of indicators can be selected for different landscapes depending on their characteristics, new indicators can be incorporated as well. Consequently it allows evaluating natural, historic, contemporary man-made structures in landscapes relevant to heterogeneous rurban landscapes;

- it is compatible with other landscape aesthetic or visual assessment methodologies. Lithuania has a long lasting tradition of aesthetic landscape assessment and development of methodologies starting from 1966 (Kamičaitytè-Virbašienè, 2003). It is possible to make a presumption that Lithuanian methodologies correspond to the peculiarities of country's landscape and could be adapted for the assessment of rurban landscapes as well. In order to test this presumption and the compatibility of the approach by M. Tveit et al. (2006) and A. Ode et al. (2008) with other methodologies, we have reviewed Lithuanian landscape aesthetic assessment approaches and also used the comprehensive review by J. Kamičaitytè-Virbašienè (2003) (table 4).

Our analysis of Lithuanian landscape aesthetic assessment methodologies and comparison with of the approach by M. Tveit et al. (2006) and A. Ode et al. (2008) has demonstrated that the majority of criteria used in Lithuanian landscape aesthetic assessment methodologies directly or partially correspond to the concepts of the comprehensive methodology of visual landscape characterization by M. Tveit et al. (2006) and A. Ode et al. (2008) (Table 5). Moreover, Lithuanian landscape aesthetic assessment methodologies mainly focus on natural (by Ėringis and Budriūnas), rural (by Bučas) landscapes, especially valuable, picturesque landscapes, suitable for recreation (by Stauskas and by Daniulaitis). Our analysis demonstrates that the majority

Table 4. Lithuanian landscape assessment approaches summarized from J. Kamičaitytè-Virbašienè (2003)

\begin{tabular}{|c|c|c|c|}
\hline \multicolumn{3}{|c|}{ Methodology } & \multirow[t]{2}{*}{ Criteria } \\
\hline Title & Author(-s) & Year & \\
\hline $\begin{array}{l}\text { Assessment of Lithuania's } \\
\text { aesthetic resources }\end{array}$ & $\begin{array}{l}\text { K. Ėringis and } \\
\text { A. R. Budriūnas }\end{array}$ & 1966 & $\begin{array}{l}\text { Expressiveness of relief, presence of water bodies, presence of } \\
\text { forests, suitability for recreation }\end{array}$ \\
\hline $\begin{array}{l}\text { Methodology for aesthetic- } \\
\text { recreational assessment of } \\
\text { landscape }\end{array}$ & $\begin{array}{l}\text { K. Ėringis and } \\
\text { A. R. Budriūnas }\end{array}$ & 1970 & $\begin{array}{l}\text { General impression, expressiveness of relief, spatial diversity } \\
\text { of vegetation, appropriateness and diversity of man-made objects }\end{array}$ \\
\hline $\begin{array}{l}\text { Methodology for analysis } \\
\text { of psychological-aesthetic } \\
\text { potential of landscape }\end{array}$ & M. Purvinas & 1982 & $\begin{array}{l}\text { Type of landscape spatial structure, naturalness, diversity, } \\
\text { general psychological-aesthetic potential }\end{array}$ \\
\hline $\begin{array}{l}\text { Methodology for landscape } \\
\text { aesthetic quality assessment }\end{array}$ & V. Stauskas & 1966 & $\begin{array}{l}\text { Objective: relief height, size and character of water bodies, } \\
\text { character and spatial structure of vegetation and land surface, } \\
\text { links between relief, water bodies and vegetation, spatial } \\
\text { structure of man-made elements; Subjective: general impression, } \\
\text { visibility, uniqueness, diversity, colorfulness, importance of } \\
\text { man-made elements, associative elements }\end{array}$ \\
\hline $\begin{array}{l}\text { Landscape ranking / applied } \\
\text { landscape geography; } \\
\text { Psychonomic analysis of } \\
\text { territory }\end{array}$ & P. Kavaliauskas & 1975 & $\begin{array}{l}\text { Aesthetic potential: expressiveness of structure, compositional } \\
\text { harmony, individuality of structure, meaningfulness of } \\
\text { expression, viability of environment; Visual expressiveness: } \\
\text { degree of culturization, orographic subdivision, water bodies, } \\
\text { character of built-up areas, type of vegetation }\end{array}$ \\
\hline $\begin{array}{l}\text { Landscape ranking / applied } \\
\text { landscape geography }\end{array}$ & G. J. Daniulaitis & 1970-1980 & $\begin{array}{l}\text { Landscape health, diversity, uniqueness, purposefulness, } \\
\text { compositional harmony }\end{array}$ \\
\hline $\begin{array}{l}\text { Methodology for aesthetic } \\
\text { quality assessment of } \\
\text { agrarian flatlands landscape }\end{array}$ & V. Palys & 1979 & $\begin{array}{l}\text { Functionality: naturalness, natural diversity, technological } \\
\text { optimality, Compositional harmony: diversity, individuality, } \\
\text { clarity, cultural-historic significance }\end{array}$ \\
\hline $\begin{array}{l}\text { Landscape formation } \\
\text { criteria }\end{array}$ & K. Šešelgis & 1975 & $\begin{array}{l}\text { Regional identity, optimal location of visual landmarks and } \\
\text { accents and their exposition in landscapes, compositional } \\
\text { harmony of buildings and natural components, diversity of visual } \\
\text { spaces, minimization of landscape visual pollution, protection of } \\
\text { picturesque natural landscape }\end{array}$ \\
\hline $\begin{array}{l}\text { Assessment of visual } \\
\text { character and compositional } \\
\text { aspects of spatial structure } \\
\text { of rural landscape }\end{array}$ & J. Bučas & $\begin{array}{l}1980 \\
1983\end{array}$ & $\begin{array}{l}\text { Compactness, proportion, hierarchy, complexity, integrity of } \\
\text { compositional structure }\end{array}$ \\
\hline $\begin{array}{l}\text { Visual landscape quality } \\
\text { assessment criteria }\end{array}$ & $\begin{array}{l}\text { J. Kamičaitytè- } \\
\text { Virbašienè }\end{array}$ & 2001,2003 & $\begin{array}{l}\text { Viability, diversity, complexity, harmony, expressiveness, } \\
\text { uniqueness, functionality, meaningfulness }\end{array}$ \\
\hline
\end{tabular}


of the criteria used in Lithuanian landscape aesthetic assessment methodologies correspond to the concepts complexity, coherence, imageability and naturalness from M. Tveit et al. (2006) and A. Ode et al. (2008) methodology. This is important, although insufficient for rurban landscape assessment, where the urban dimension is equally important. Here the concepts, such as disturbance, stewardship, and historicity are no less relevant. The concept of ephemera, meaning seasonal change is of high relevance to Lithuanian landscapes in general.
Analysis demonstrate that some approaches used in Lithuanian landscape aesthetic assessment methodologies can be successfully integrated into the methodology by M. Tveit et al. (2006) and A. Ode et al. (2008). For example, distinguishing the visual spaces used by P. Kavaliauskas (1975) and M. Purvinas (1982) can be applied determining visual scale; assessment of visual character and compositional aspects of spatial structure of rural landscape by J. Bučas (1980; 1983) can be used in determining coherence, imageability and historicity of rurban landscapes.

Table 5. Correspondence of landscape assessment methodologies and landscape aesthetics theories. With reference to J. KamičaitytèVirbašiene (2003), M. Tveit et al. (2006) and A. Ode et al

\begin{tabular}{|c|c|c|c|}
\hline \multirow[t]{2}{*}{$\begin{array}{l}\text { Landscape } \\
\text { aesthetics theory }\end{array}$} & \multicolumn{2}{|c|}{$\begin{array}{l}\text { Methodology by A. Ode et al. and } \\
\text { M. Tveit et al. }\end{array}$} & \multirow{2}{*}{$\begin{array}{l}\text { Lithuanian landscape aesthetic assessment methodologies } \\
\text { Corresponding criteria }\end{array}$} \\
\hline & Concept & Short description & \\
\hline $\begin{array}{l}\text { Biophilia, } \\
\text { Information } \\
\text { processing theory }\end{array}$ & Complexity & $\begin{array}{l}\text { Diversity, variation, } \\
\text { richness, complexity } \\
\text { of patterns and shapes, } \\
\text { spatial pattern / } \\
\text { combination }\end{array}$ & $\begin{array}{l}\text { expressiveness of relief, spatial diversity of vegetation, diversity of } \\
\text { man-made objects (Ëringis and Budriūnas), diversity (Purvinas), relief } \\
\text { height, diversity, colorfulness, importance of man-made elements } \\
\text { (Stauskas), expressiveness of structure, character of built-up areas } \\
\text { (Kavaliauskas), diversity (Daniulaitis), diversity (Palys), diversity } \\
\text { of visual spaces (Šešelgis), complexity, hierarchy (Bučas), diversity, } \\
\text { complexity, expressiveness (Kamičaitytè-Virbašienè) }\end{array}$ \\
\hline $\begin{array}{l}\text { Information } \\
\text { processing theory }\end{array}$ & Coherence & $\begin{array}{l}\text { Correspondence } \\
\text { with ideal situation, } \\
\text { harmony, unity, } \\
\text { holistic, land-use } \\
\text { suitability, balance and } \\
\text { proportion, intactness }\end{array}$ & $\begin{array}{l}\text { presence of water bodies, suitability for recreation, appropriateness } \\
\text { of man-made objects (Ėringis and Budriūnas), general psychological- } \\
\text { aesthetic potential (Purvinas), size and character of water bodies, } \\
\text { links between relief, water bodies and vegetation, general impression } \\
\text { (Stauskas), compositional harmony, water bodies (Kavaliauskas), } \\
\text { purposefulness, compositional harmony (Daniulaitis), clarity, } \\
\text { technological optimality (Palys), optimal location of visual landmarks } \\
\text { and accents and their exposition in landscapes, compositional harmony } \\
\text { of buildings and natural components (Šešelgis), proportion, hierarchy, } \\
\text { integrity of compositional structure (Bučas), harmony, functionality } \\
\text { (Kamičaitytė Virbašienè) }\end{array}$ \\
\hline Biophilia & Disturbance & $\begin{array}{l}\text { Intrusion, alteration, } \\
\text { impact, lack of } \\
\text { contextual fit, lack of } \\
\text { coherence }\end{array}$ & minimization of landscape visual pollution (Šešelgis) \\
\hline Aesthetics of care & Stewardship & $\begin{array}{l}\text { Sense of order, sense of } \\
\text { care, upkeep }\end{array}$ & $\begin{array}{l}\text { purposefulness (Daniulaitis), technological optimality (Palys), } \\
\text { functionality (Kamičaitytè-Virbašienè) }\end{array}$ \\
\hline $\begin{array}{l}\text { Spirit of place } \\
\text { / genius loci, } \\
\text { Vividness, } \\
\text { Topophilia }\end{array}$ & Imageability & $\begin{array}{l}\text { Sense of place, } \\
\text { genius loci, place } \\
\text { identity, uniqueness, } \\
\text { distinctiveness, } \\
\text { vividness }\end{array}$ & $\begin{array}{l}\text { suitability for recreation (Ėringis and Budriūnas), general } \\
\text { psychological-aesthetic potential (Purvinas), general impression, } \\
\text { uniqueness, associative elements (Stauskas), individuality } \\
\text { of structure, meaningfulness of expression (Kavaliauskas), } \\
\text { uniqueness (Daniulaitis), individuality, cultural-historic significance } \\
\text { (Palys), regional identity (Šešelgis), expressiveness, uniqueness, } \\
\text { meaningfulness (Kamičaitytė-Virbašienè) }\end{array}$ \\
\hline $\begin{array}{l}\text { Prospect-refuge } \\
\text { theory, Information } \\
\text { processing theory }\end{array}$ & Visual scale & $\begin{array}{l}\text { Landscape room, } \\
\text { visibility, openness, } \\
\text { enclosure, } \\
\text { spaciousness, grain size }\end{array}$ & $\begin{array}{l}\text { type of landscape spatial structure (Purvinas), character and spatial } \\
\text { structure of vegetation and land surface, spatial structure of } \\
\text { man-made elements, visibility (Stauskas), orographic subdivision } \\
\text { (Kavaliauskas), compactness (Bučas) }\end{array}$ \\
\hline $\begin{array}{l}\text { Restorative } \\
\text { landscapes, } \\
\text { Biophilia, } \\
\text { Ecological } \\
\text { aesthetics }\end{array}$ & Naturalness & $\begin{array}{l}\text { Intactness, wilderness, } \\
\text { natural, ecologically } \\
\text { robust, vegetation } \\
\text { health }\end{array}$ & $\begin{array}{l}\text { presence of forests (Ëringis and Budriūnas), naturalness (Purvinas), } \\
\text { viability of environment, degree of culturization, type of vegetation } \\
\text { (Kavaliauskas), landscape health (Daniulaitis), naturalness, natural } \\
\text { diversity (Palys), protection of picturesque natural landscape (Šešelgis), } \\
\text { viability (Kamičaitytė-Virbašienė) }\end{array}$ \\
\hline $\begin{array}{l}\text { Topophilia, } \\
\text { Landscape heritage } \\
\text { / historic landscapes }\end{array}$ & Historicity & $\begin{array}{l}\text { Historical continuity, } \\
\text { historical richness }\end{array}$ & $\begin{array}{l}\text { associative elements (Stauskas), character of built-up areas } \\
\text { (Kavaliauskas), cultural-historic significance (Palys), meaningfulness of } \\
\text { expression (Kavaliauskas), meaningfullness (Kamičaitytè-Virbašienè) }\end{array}$ \\
\hline $\begin{array}{l}\text { Restorative } \\
\text { landscapes }\end{array}$ & Ephemera & $\begin{array}{l}\text { Seasonal change (human } \\
\text { imposed and natural), } \\
\text { weather changes }\end{array}$ & colorfulness (Stauskas) \\
\hline
\end{tabular}




\section{Recommendations for modeling the image of rurban landscapes}

According to J. Kamičaitytè-Virbašienè (2003), developed countries devote considerable attention to landscape visual resources as an important public good in theoretical, legal, administrative, and practical planning levels. According to her, the system of regulation of landscape visual resources may encompass landscape analysis and assessment, distinguishing the territories of different visual quality with different concepts of development of visual environment (visual landscape model), regulation of visual quality changes - integration of visual quality goals into territorial planning documents, assessment of visual impact on environment. After the analysis of literature, including works by J. Kamičaitytè-Virbašienè (2001; 2003) on landscape visual quality regulation in land management, the practical experience of landscape valuation in the United States of America, in Great Britain, Poland, Spain, Portugal, analysis of peculiarities of rurban landscapes in general and Lithuanian rurban landscapes in particular, we have formulated theoretical proposals for aesthetic development of these landscapes (Fig. 1).

- The development of aesthetic image of rurban landscapes must be an integral part of their overall sustainable development but not an isolated goal in itself; it must be integrated in every stage of the general sequence of landscape development process from its beginning. The landscape itself has a multi-functional character, it performs ecological function, aesthetic function, cultural-historical function (heritage objects, land use structure, historical associations), functions of tourism and information (recreation, environmental education, interpretation), functions of resources and land use (habitat, agricultural or forestry production, water yield etc.) (Rasa and Nikodemus
2008); consequently planning and management of rurban landscape integrate sustainable functions, environmental sustainability, heritage preservation, landscape identity and aesthetics.

The approach by W. Nohl (2001) - "sustainable aesthetics" - integrates the future scenarios of sustainable development of landscapes and the possible trends of their aesthetic expression: the better or more sustainable landscape use modifies its aesthetic reality. W. Nohl (2001) argues that this may be a helpful tool in landscape planning.

- The stage of landscape analysis and assessment should integrate not only the functional, ecological, heritage preservation, socioeconomic and other aspects but also landscape aesthetic assessment. The dynamic character of rurban landscapes requires not only the assessment of the present state, but also of possible different trends of future development (urbanization, abandonment, re-naturalization etc.) if no measures would be taken. The above presented methodology by M. Tveit et al. (2006) and A. Ode et al. (2008) can be applied for the aesthetic assessment of the present state and possible development trends; the SWOT (strengths, weaknesses, opportunities, and threats) analysis and comparative analysis of the present state and future hypothetical situations can be carried out.

- Zoning of the territory under analysis should integrate the typology of rurban landscapes according to the degree of urbanization (Zaleskienè and GražulevičiūtèVileniškè, 2013), the presence of the relicts of historic rurban landscape and aesthetic quality. Four or more classes of aesthetic quality can be distinguished. Distinguishing aesthetic classes it should be noted that different concepts or sets of concepts are more important for different categories of landscape more than others: for predominantly natural landscape with urban insertions the concepts of naturalness and ephemera are far more relevant than that of historicity,

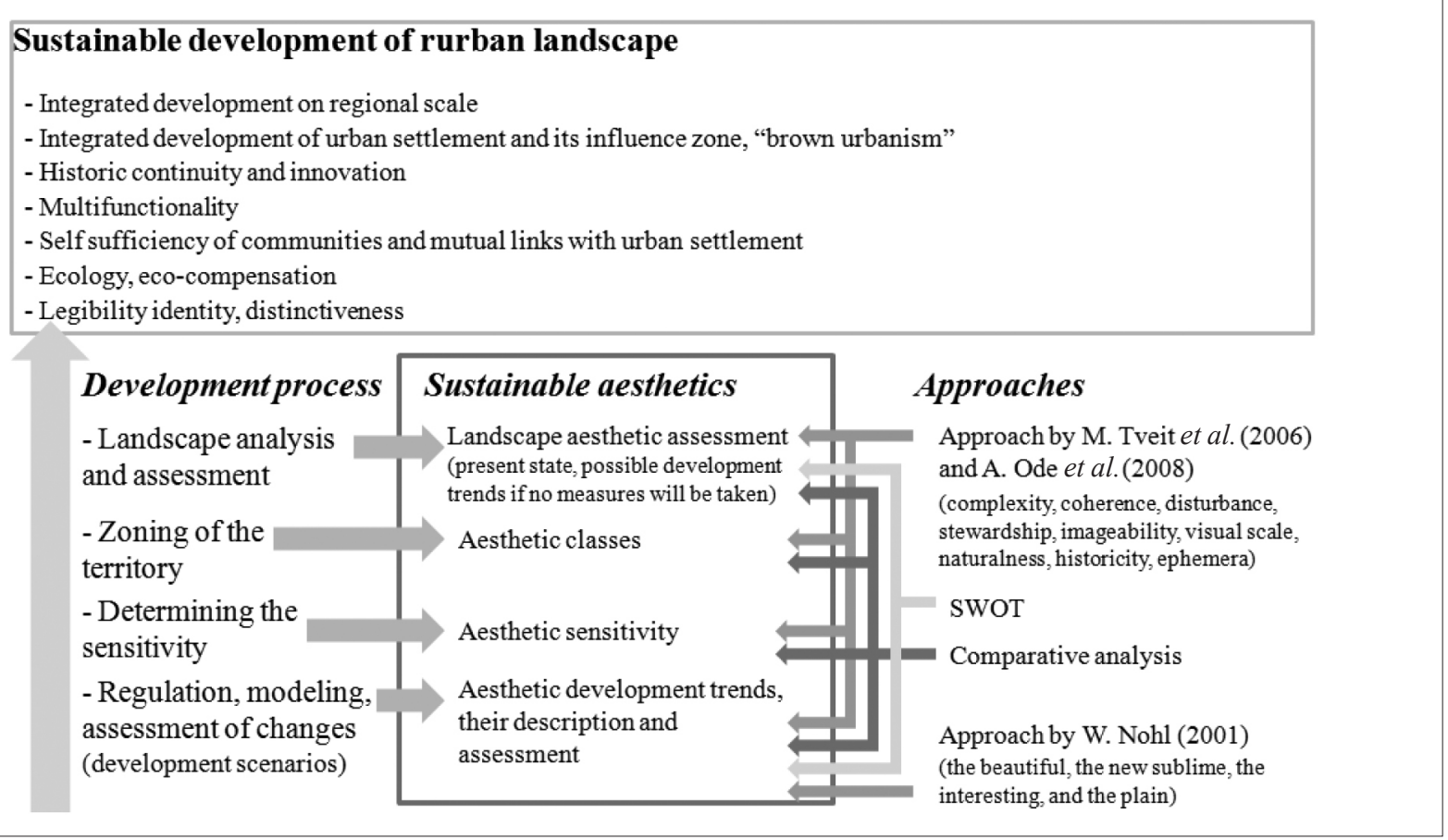

Fig. 1. Aesthetic development of rurban landscapes in the context of sustainability. Scheme by the authors 


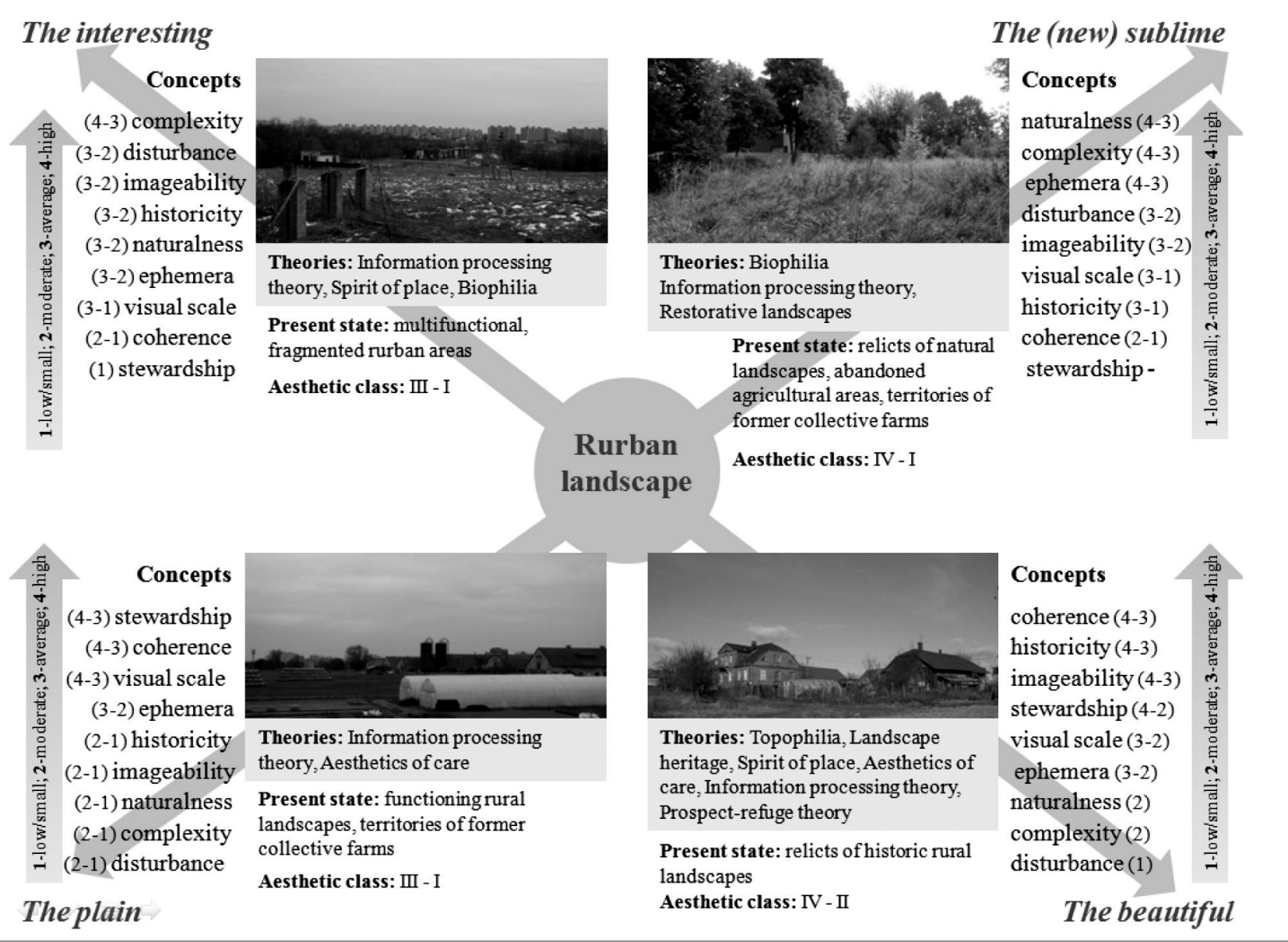

Fig. 2. Possible aesthetic development trends of different rurban landscapes: aesthetic categories by W. Nohl (2001) are used as landscape prototypes; concepts should by assessed using indicators by A. Ode et al. (2008); aesthetic classes range from IV (highest) to I (lowest); landscape aesthetics theories potentially influencing preferences towards these landscapes are indicated as well. Scheme by the authors

for rurban landscape with valuable relicts of historic rural landscape the most important concepts would be of historicity, coherence, stewardship etc. (Fig. 2).

- The sensitivity (from ecological, heritage preservation, visibility, aesthetics, social, economic and other points of view) of different zones towards landscape changes can be also determined. The higher aesthetic class, the more sensitive is the territory from the aesthetic point of view. The aesthetic sensitivity can also be influenced by the type of users (tourists, locals), quantity of users, social significance of the territory, the uses of adjacent territories, the status of protected territory (Kamičaitytè-Virbašienè, 2003).

- The regulation and modeling of changes of rurban landscapes should encompass the determining of priorities - ecological, agricultural, social (development of communities), urbanization (needs of the city), cultural, economic, industrial, heritage preservation etc. - based on the features and sensitivity of the territory and the needs of the urban settlement and construction of development scenarios based on the determined priorities. Several alternative scenarios can be developed, evaluated and compared. These scenarios may include the functions and activities, plan and spatial structure, heritage preservation requirements, desirable ecological conditions etc. and landscape aesthetics. In order to evaluate the alternative scenarios for the same area, the SWOT analysis could be carried out.

- The proposals for the aesthetic development of rurban landscapes in these scenarios should integrate the local identity (the aesthetic sense of place presupposes some history (Nohl, 2001), thus local identity can be determined not only by the features of natural landscape, but also by the relicts of historic types of rural landscapes), legibility (informational content of landscape that makes it recognizable as particular type of landscape - rurban) and distinctive aesthetic image (attractiveness and uniqueness of landscape) of rurban landscapes.

- For the description and assessment of proposed aesthetic development trends above presented methodology by M. Tveit et al. (2006) and A. Ode et al. (2008) can be applied and the assessment results can be compared: 1) between different scenarios; 2 ) with the present condition of the territory; 3 ) with the condition of the territory in the future if no measures would be taken.

- Considering the holistic approach of W. Nohl (2001) towards landscape aesthetics in the context of sustainability and simultaneously his thorough look at the future landscapes as an aesthetical objects, we argue that his four aesthetic perceptual categories under sustainable landscape conditions - the beautiful, the new sublime, the 
interesting, and the plain - can be successfully applied in modeling the aesthetics of rurban areas:

- the beautiful. According to W. Nohl (2001), speaking of "beautiful" landscape we immediately think of traditional cultural landscape. He notes that people tend to experience those landscape areas as beautiful, where, like in traditional cultural landscapes, all elements are more or less known and in which these elements are arranged in balanced and harmonic - "beautiful" - order, and each of them is in the expected place and describes such landscapes with terms richness of symbolic meanings, unity, harmony.

In the areas of rural-urban interface the relicts of historic rural landscapes maintained or restored could create this aesthetic category. W. Nohl (2001) notes that remnants bear a certain future orientation - thus these historic relicts can acquire new urban-oriented functions and can be integrated into increasingly urbanized landscape.

- the new sublime. Sustainable landscapes must contain areas, where nature can develop freely and spontaneously and such parts of landscape simultaneously can be very informative and aesthetically appealing, as W. Nohl (2001) notes. According to W. Nohl (2001) and A. Jorgensen (2011), strong ecological, environmental orientation, resulting from the massive destruction of nature and from the threat of ecological disasters influences aesthetic landscape perception. W. Nohl (2001) uses the old concept "sublime" to describe the new aesthetic category, generated by the selfdynamics, self-productivity, self-regulation power of nature, demonstrating that not everything on earth depends on human will and human power. He characterizes these landscapes as disharmonic, unordered, fragmented, unstable, not easy to read, mysterious. This aesthetic category can be easily applied in the rurban areas as a part of productive or recreational landscape. Moreover, spontaneous re-naturalizing landscapes are important from ecological and educational points of view. For example, the new sublime landscapes may emerge in the abandoned agricultural land and farming complexes in the areas of rural-urban interface.

- the interesting. This aesthetic category, according to W. Nohl (2001), is related to landscapes, where a multiplicity of land uses generate confusing, incoherent, labyrinthine, chaotic environments and events; however, the interesting in the right place affects us positively even if it includes ugly things. This aesthetic category of landscape is full of contradictions - designed and undesigned, beautiful and ugly, new and familiar, bizarre and usual, known and mysterious (Nohl, 2001) - and very well corresponds to the nature of mutable, transitory rurban landscapes. Rural landscapes with small isolated islands of suburban housing, abandoned farming buildings and equipment, unusual combinations of spontaneous nature and logistics, commercial, infrastructure buildings can embody this aesthetic category. Of course these confusing interesting landscapes must be structured by larger landscape areas, by natural elements and areas (Nohl, 2001).

- the plain. The aesthetic quality of the areas of ecologically sound intensive agricultural production - rural functional landscapes - embodies the aesthetic category "the plain". This aesthetic category, even if not so appealing and pleasing, shows how the nature and man-made could be reconciled, generates the feelings of contentment and gratitude (Nohl 2001). The aesthetic category "the plain" and the agricultural function it corresponds to can be successfully accommodated in the rurban areas (for example, in the territories of former collective farms), thus limiting the urban sprawl and providing agricultural products for the city.

- It may be possible to use only one of these categories, but often several or all of them would be necessary for characterization of the aesthetic state (Nohl, 2001) of the certain rurban landscape.

- In order to avoid uniformity or similarity of rurban landscapes these aesthetic prototypes should be differentiated by local regional variations into multiplicity of single, unique landscapes (Nohl, 2001). The factors that would work together with the aesthetic categories creating the local identity and uniqueness of each rurban landscape are local ethnographic traditions embodied in historic rural architecture and landscape management, historic relicts of rural landscape, features of natural landscape, urban expansion trends etc.

\section{Conclusions}

1. Visual quality of landscape or, more generally, landscape aesthetics is an important component of quality of life, landscape identity and landscape sustainability. That's why it is important not only to protect valuable aesthetic resources - natural and cultural picturesque landscapes or historic cityscapes - but also to take care of the aesthetic dimension of our everyday environment including the constantly expanding areas of rural-urban interface.

2. The excising landscape aesthetics theories can be subdivided into evolutionary or biological (Prospect-refuge theory, Information processing theory, Human habitat theory, Biophilia hypothesis), cultural (Landscape heritage, Spirit of place, Aesthetic of care) and mixed (Restorative landscapes, Ecological aesthetics, Topophilia) (Ode et al., 2008; Tveit et al., 2006). After the analysis whether and how they can be applicable to rurban landscapes, we have concluded that all the theories are potentially applicable to these landscapes due to their heterogeneous character encompassing rural, natural, urban features and combining heritage and innovations.

3. The analysis of Lithuanian experience of landscape aesthetic assessment has demonstrated that these approaches and criteria applied correspond with the internationally 
known approaches and landscape aesthetic theories and can be integrated into rurban landscape valuation.

4. The applicability of above-mentioned landscape aesthetics theories to rurban landscapes allows concluding that the system of visual characterization concepts - complexity, coherence, disturbance, stewardship, imageability, visual scale, naturalness, historicity, ephemera - developed by M. Tveit et al. (2006) and A. Ode et al. (2008) based on these theories can be applied to various categories of rurban landscapes. Thus, both the present state and the envisioned landscape changes can be evaluated using this approach. The desirable image, aesthetic character and identity of rurban landscapes are important yet often ignored issues. In this research we present the idea that the aesthetic perceptual categories under sustainable landscape conditions - the beautiful, the (new) sublime, the interesting, and the plain - elaborated by W. Nohl (2001) can be used as a basis for development of distinctive image of rurban areas.

\section{References}

Antrop M. 2008. Landscapes at risk: about changes in European Landscape. In: Dostal P. (Ed.) Evolution of geographical systems and risk processes in the global context. Prague, Charles University, 57-79.

Appleton J. 1975. The Experience of Landscape. London, Wiley.

Bučas J. 1983. Kai kurie kaimo kraštovaizdžio kompozicijos aspektai. Lietuvos TSR architektūros klausimai, T. 8, Sąs. 1, 70-76.

Bučas J. 1980. Kai kurios agrarinio kraštovaizdžio vizualinès charakteristikos. Lietuvos TSR architektūros klausimai, T. 6, Sąs. 3, $78-86$.

Burgess D., Finney G., Mathews D., Patton M. 2012. Landscape valuation: choice experiments or contingent valuation? Available at: http://ageconsearch. umn.edu/bitstream/134984/2/Diane_Burgess AES\%25202012\%2520Burgess.pdf (accessed 03 March 2014).

Daniulaitis G. J., Kamičaitytė-VirbašienėJ. 2002. Kraštovaizdžio estetinès ir vizualinès kokybès problema kraštotvarkoje. In: Kraštovaizdžio vizualinė kokybė: konferencijos pranešimų medžiaga. Kaunas, 16-23.

Daniulaitis G. 1980. Rekreacinio landšafto formavimas planuojant rajonus. Lietuvos TSR architektūros klausimai, T. 6, Sąs. 3, 127.

Ėringis K., Budriūnas A. R. 2000. Kraštovaizdžio estetinio rekreacinio vertinimo metodika. Vilnius, Botanikos institutas.

Ewald K. C. 2001. The neglect of aesthetics in landscape planning in Switzerland. Landscape and Urban Planning, 54, 255266. http://dx.doi.org/10.1016/S0169-2046(01)00140-2

Heimer H. 2005. Topophilia and Quality of Life: Defining the Ultimate Restorative Environment. Environmental Health Perspectives, 113(2), A117. http://dx.doi.org/10.1289/ehp.113-a117

Jacobs P. 2011. Where have all the flowers gone? Landscape and Urban Planning, 100, 318-320.

http://dx.doi.org/10.1016/j.landurbplan.2011.01.021
Jorgensen A. 2011. Beyond the view: future directions in landscape aesthetics research. Landscape and Urban Planning, 100, 353-355. http://dx.doi.org/10.1016/j. landurbplan.2011.02.023

Kamičaitytė-Virbašienè J. 2003. Kraštovaizdžio vizualinės kokybės reguliavimas kraštotvarkoje (Lietuvos pavyzdžiu): daktaro disertacija [Landscape visual quality in environmental design (sample of Lithunia)]. Kaunas, Technologija.

Kamičaitytė-Virbašienè J. 2001. Kraštovaizdžio vizualinè kokybè, jos reguliavimo svarba ir problemos. Urbanistika ir architektūra, 25(4), 202-210.

Kaplan R., Kaplan S. 1989. The Experience of Nature: A Psychological Perspective. New York, Cambridge University Press.

Kavaliauskas P. 1975. Kraštovaizdžio grožis ir būdai jam išmatuoti. Statyba ir architektūra, 8, 33-26.

Munro T. 2013. Aesthetics. Encyclopaedia Britanica. Available at: http:/www.britannica.com/EBchecked/topic/7484/ aesthetics (accessed 27 February 2014).

Musacchio R. L. 2009. The scientific basis for the design of landscape sustainability: a conceptual framework for translational landscape research and practice of designed landscapes and the six Es of landscape sustainability. Landscape Ecology, 24. 993-1013. http://dx.doi. org/10.1007/s10980-009-9396-y

Nassauer J. I. 1995. Messy Ecosystems, Orderly Frames. Landscape Journal, 14(2), 161-170.

Nassauer J. I., 2007. Cultural Sustainability: Aligning Aesthetics and Ecology. In: Nature, Aesthetics, and Environmentalism. A. Carlson and S. Lintott, eds., New York, Columbia University Press, 363-379.

Nassauer, J. I. 1988. The Aesthetics of Horticulture: Neatness as a Form of Care. HortScience, 23(6), 973-977.

Nohl W. 2001. Sustainable landscape use and aesthetic perception - preliminary reflections on future landscape aesthetics. Landscape and Urban Planning, 54, 223-237. http://dx.doi.org/10.1016/S0169-2046(01)00138-4

Ode A., Tveit M. S., Fry G. 2008. Capturing landscape visual character using indicators: touching base with landscape aesthetic theory. Landscape Research, 33(1), 89-117. http://dx.doi.org/10.1080/01426390701773854

Purvinas M. 1982. Subjektyvus kraštovaizdžio vertinimas. Lietuvos TSR architektūros klausimai, T. 8, Sąs. 1, 60-67.

Rasa I., Nikodemus O. 2008. The influence of land use structural changes on the landscape ecological, aesthetic and culturalhistorical values of the Gauja National Park, Latvia. Land use changes and ecological, aesthetic and cultural values, 83-93. Available at: http://old.va.lv/files/biodiversity-rasa. pdf (accessed 7 June 2013).

Slater B. H. 2014. Aesthetics. Internet Encyclopedia of Philosophy. Available at: http://www.iep.utm.edu/aestheti/ (accessed 27 February 2014)

Stauskas V. 1966. Landšafto vertinimo metodika planuojant poilsio rajonus. Lietuvos TSR architektūros klausimai, T. 3, Sąs. 5, 184-206.

Stedman R. C., Ingalls M. (2014) Topophilia, Biophilia and Greening in the Red Zone. In: Tidball K., M. Krasny (Eds) Greening in the Red Zone: Disaster, Resilience, 
and Community Greening. Netherlands, Springer. Available at: http://link.springer.com/chapter/10.1007\% 2F978-90-481-9947-1_10 (accessed 12 March 2014)

Steinitz C. 1990. Towards a Sustainable Landscape with High Visual Preference and High Ecological Integrity. Landscape and Urban Planning, 19, 213-250. http://dx.doi.org/10.1016/0169-2046(90)90023-U

Swanwick C. 2002. Landscape Character Assessment: Guidance for England and Scotland. London: The Countryside Agency and Scottish Natural Heritage.

Šešelgis K. 1975. Rajoninio planavimo ir urbanistikos pagrindai. Vilnius, Mintis.
Tveit M., Ode A., Fry G. 2006. Key concepts in a framework for analysing visual landscape character. Landscape Research, 31(3), 229-255. http://dx.doi. org/10.1080/01426390600783269

Zaleskienè E., Gražulevičiūtè-Vileniškè I. 2013. Rurban Landscape Classification: Case of Lithuania. In: Proceedings of the 6th international conference Rural Development 2013. November 28-29 2013, Aleksandras Stulginskis University, Akademija, 6(1), 463-467.

Zaleskienė E., Kamičaitytė-Virbašienė, J., GraluževičiūtèVileniškè, I. 2013. Aesthetic aspects of landscapes in the rural-urban interface zones. Acta Biologica Universitatis Daugavpiliensis, 1(13), 15-30.

Erika ZALESKIENE - Ph.D. student at Kaunas University of Technology, Faculty of Civil Engineering and Architecture, Department of Architecture and Urbanism.

Main research areas: formation of green areas, rural-urban interface, rurban landscapes.

Address: Kaunas University of Technology, Faculty of Civil Engineering and Architecture, Studentu st. 48, LT-51367 Kaunas, Lithuania.

Tel.: $\quad+37037451546$

E-mail: erika.brinkyte@gmail.com

Indrė GRAŽULEVIČIŪTĖ-VILENIŠKE் - associated professor at Kaunas University of Technology, Faculty of Civil Engineering and Architecture, Department of Architecture and Urbanism.

Main research areas: valuation and preservation of cultural heritage, management of rural-urban interface, sustainable architecture.

Address: Kaunas University of Technology, Faculty of Civil Engineering and Architecture, Studentu st. 48, LT-51367 Kaunas, Lithuania.

Tel.: $\quad+37037451546$

E-mail: indre.grazuleviciute@ktu.lt 